\title{
Relationship between Perceived Organizational Politics, Supportive Organizational Climate and Job Satisfaction in Thai Higher Education Sector
}

\author{
Md Abdus Salam \\ Lecturer-Business Administration, St. Theresa International College, Thailand
}

\author{
Doi:10.5901/mjss.2016.v7n5p396
}

\begin{abstract}
Faculty job satisfaction is undoubtedly important to provide quality education to the future graduates of the country. Supportive organizational climate and perceived organizational politics have huge impact on job satisfaction. Keeping that in mind this study explores the job satisfaction and its relationship with perceived organizational politics and supportive organizational climate. Sample of this study includes 105 faculty currently teaching in three different private higher education institutes in Thailand. Result of the study shows that faculty job satisfaction has significant positive relation with supportive organizational climate and significant negative relation with perceived organizational politics. However, no role of supportive organizational climate is found on job satisfaction-POP relationship.
\end{abstract}

Keywords: Job satisfaction, perceived organizational politics (POP), supportive organizational climate, Thai higher education

\section{Introduction}

Although detrimental effects of organizational politics were well-known, it has been ignored in literature for a long time. Last couple of decades researches are found to be aware of adverse effect of such negative behaviour in the workplace. Generally organizational politics is a set of behaviours performed to enhance or attain self-interest by any means even sometime at the cost of organizational goals (Mintzberg, 1985).

There are two views of organizational politics; the first one is objective view, which focuses on the political tactics as an instance supervisor focused tactics which comes along with the higher career achievement rather than self promotion strategies (Judge \& Bretz, 1994). Another view of organizational politics is subjective one which explains one's view of politics inside the organization and thus called perceived organizational politics. As organizational politics is state of mind or behavioural state, researchers mostly focused on later one and explored the reaction of individuals on their perception of politics (Cropanzano, Howes, Grandey, \& Toth, 1997; Ferris \& Kacmar, 1992; Randall, Cropanzano, Bormann, \& Birjulin, 1999). There are several outcomes of organizational politics pointed out by researchers such as increased stress (Ferris, Frink, Galang, Zhou, Kacmar, \& Howard, 1996), reduced organizational commitment (Cropanzano et al., 1997), intention to turnover (Cropanzano et al., 1997; Ferris et al., 1993), job dissatisfaction (Cropanzano et al., 1997; Bozeman, Perrewe, Hochwarter, Kacmer, \& Brymer, 1996) and so on. Objective of this paper is to explore relationship between perceived organizational politics, supportive organization climate and job satisfaction and role of organizational climate on that relationship in Thai higher education sector.

Education system is the backbone of development of any nation and it never performs better without teachers/faculty spontaneous performance in the organization (Selamat, Samsu, \& Kamalu, 2013). This research based on Thai higher education system where development has become urgent. As job dissatisfaction leads to underperformance of the employee, here relationship of satisfaction with perception of organizational politics is measured.

\section{Literature Review}

\subsection{Perceived Organizational Politics}

Like other organizational phenomena organizational politics also has several definitions. For the purpose of this research Mintzberg's (1983) definition of organizational politics is adopted. According to him organizational politics is the activities that are not consistent with organizational norms, basically performed for self-interest and disregarding organizational goals, sabotaging others and withholding negative but important information/result from the management (Mintzberg, 
1983).

Ferris, Russ and Fandt (1989) added extra dimension in this definition, they argue that self-interest could be both short term and long term and might come at the expense of organizational as well as other individuals' interest. Cropanzano, Kacmar, and Bozeman (1995) elaborate further by adding that such activities could be "covert, crafty, and behind the scenes" (pp. 7).

Although such behavior considered illegitimate for organizations, it could be possible that such behavior is well rooted in the power distribution, resource allocation, reward and punishment process based on cultural and contextual factors (Khalil \& Ahmed, 2016). Hence, besides maximizing self-interest such behavior may aim to safeguard individuals from the negative outcomes of any form in the organization (Vigoda-Godot \& Talmud, 2010).

Empirical studies on organizational politics mostly based on the model of Ferris, et al. (1989) who argued that organizational politics can be better explained as a human psychological state i.e., perception of politics in the organization. Several research also found that people form attitudes and behave based on their perception of any situation rather than the actual situation (Porter, 1976; Ferris, Adams, Kolodinsky, Hochwarter, \& Ammeter, 2002; Breaux, Munyon, Hochwarter, \& Ferris, 2009). As expected, empirical evidences shows negative effect of perceived organizational politics on performance, satisfaction, turnover intention and so on (Kacmar \& Baron, 1999).

Kacmar and Ferris (1991) divided POP into three dimensions such as general political behavior (GPB), go along to get ahead and pay and promotion policies.

\subsubsection{General Political Behavior}

This dimension states that when the organization as an entity submerged in politics, then an individual also explores the ways through politics to maximize own benefit (Drory \& Romm 1990; Fandt \& Ferris, 1990; Ferris \& King, 1991). This type of practice occurs in a place where environment allows individuals with political skill to perform activities for maximizing self-interest. Organizations lacking rules and regulations of appreciated and appropriate behavior and relax reward and punishment policies might provide such environment.

\subsubsection{Go along to get ahead}

This dimension of organization politics originated from the idea that conflict is an inevitable component of organization rich in politics and individuals may response to that conflict in different ways (Gandz \& Murray, 1980; Mintzberg, 1985; Porter, Allen, \& Angle, 1981). This dimension indicates such a behavior which provides support to specific group silently.

Organization politics creates several groups in the organization, people chose group to maximize self-benefit, but by doing so there is a high potential to harm others self-interest and conflict becomes unavoidable. To evade such conflict some individuals may silently support specific group/person; according to Frost (1987) if anyone does so to attain selfinterest that is also a political behavior. Kacmar and Carlson (1997) believe that this could be a very effective political strategy in a political environment to gain self-interest without exposing much.

\subsubsection{Pay and Promotion Policies}

This dimension of organization politics indicates that organizational policies and practices regarding promotion and pay may lead individuals to behave politically (Kacmar \& Ferris, 1993). It does not mean that senior management necessarily involved in the politics rather their policy and practice of promoting such people may give a wrong signal to the organization climate. In organizations where reward and promotion are not based on real evaluation of performance rather based on perceived performance and 'face value', employees are highly motivated to behave politically to attain self-gain. Once such behavior is rewarded it brings more such activities in future (Kacmar \& Carlson, 1997).

\subsection{Job Satisfaction}

There are various definitions of job satisfaction, in simple words job satisfaction is employees' level of satisfaction in their job and workplace (Gohel, 2012). That means it indicates employees expectation from their job and workplace. Hence, employees' level of satisfaction might increase if they are provided with benefits and workplace climate as they expected (Yang, 2010). From another point of view job satisfaction is a psychological state of employees. It could be explained as psychological phenomenon which states that employees evaluate their satisfaction base on previous events and present impressions (Ko, 2012). Islam, Rasul, and Ullah (2012) also figures out that job satisfaction is consisted with many attitudinal objects like job itself, compensation and benefits, environment and so on. 


\subsection{POP and Job Satisfaction}

Employer or management provides salary increase, better benefits, training opportunities, career growth and so on whereas co-workers provide social relationship in the workplace. Organizational politics affects both types of relationship, on one hand it influences employer-employee relationship in increment, training and other aspects (Cropanzano, et al., 1997), and on the other hand it pollutes the social environment in the organization (Keeley, 1988). Kacmar and Baron (1999) cited 11 studies which explored job satisfaction as an outcome of organizational politics. They believe that job satisfaction is the most explored relationship with organizational politics (at least until their study). Using Ferris et al. (1989) model researchers discovered that employees with high organizational politics perception are dissatisfied with their job and on the contrary lower organizational politics perception brings higher job satisfaction.

\subsection{Supportive Organizational Climate}

Researchers have taken multiple paths to define organizational climate. Thompson (2005) defines organizational climate as an approach of observing and characterizing the organizational environment by employees of the organization in an "attitudinal" and "value-based" way. Some other defines this as an equation of employee performance which includes employees' ability, received support and given effort (Schermerhorn, Gardner, \& Martin, 1990). That means individuals performance is the sum of their ability, support received from different inner-organizational sources and being motivated and using their ability to achieve goal.

Researchers have related supportive organizational climate with employee outcomes in several research. Mercer and Bilson (1985) reported one such relationship; from their study they showed that supportive organizational climate is positively related to organizational commitment and job satisfaction. Rogg, Schmidt, Shull and Schmitt (2011) showed in their research that supportive organizational climate is positively related to organizational outcomes such as customer satisfaction. Although unlike this research that finding deals at organizational level instead of individual level, it provides a ground to check other outcomes at different level. Some other researchers tested supportive climate from the view point of perceived amount of organizational support existed in the organization (Eisenberger, Fasolo, \& Davis-LaMastro, 1990; Rhoades, Eisenberger, \& Armeli, 2001).

After reviewing previous research and theory building efforts, this study considers the supportive organizational climate as perceived level of support received by the employee from surroundings. The word surroundings indicates here immediate peers, other departments and their supervisors as in Luthans, Norman, Avolio and Avey (2008).

From above discussed review of literature this research suggests following hypotheses

$\mathrm{H} 1$ : Perceived organizational politics (POP) is negatively related to the faculty job satisfaction.

To explore further, this research suggests the relationship of the components of POP with job satisfaction. Therefore, job satisfaction's relationship with all three components/dimension of POP, general political behavior, go along to get ahead and pay and promotion policy, are also tested. Therefore,

H1A: General political behavior dimension of (POP_GP) is negatively related to job satisfaction

H1B: Go along to get ahead dimension of POP (POP_GAG) is negatively related to job satisfaction

H1C: Pay and promotion policy dimension of POP (POP_GP) is negatively related to job satisfaction

This study further suggests positive supportive organizational climate-job satisfaction relationship, which is also supported by the literature. Hence,

$\mathrm{H} 2$ : Supportive organizational climate is positively related to job satisfaction.

This research also suggests, from the discussion above, mediating role of supportive organizational climate on the POP - job satisfaction relationship.

H3: Supportive organizational climate mediate the relationship between POP and job satisfaction.

\section{Research Methodology}

Survey method is used to collect data for this research using questionnaire which includes item of job satisfaction, perceived organizational politics and supportive organizational climate along with demographic data.

\subsection{Participants}

Private university and college faculty are the participants of this research. Questionnaires were distributed both hand-tohand and electronically using survey monkey. From two private colleges and one private university in Bangkok and suburb areas total of 105 completed questionnaires have been collected. 


\subsection{Measuring Scales}

First part of this questionnaire is demographic data and then questionnaire of POP followed by the questionnaire of job satisfaction and supportive organizational climate.

\subsubsection{Job satisfaction}

Six items Five point likert scale developed by Agho, Price, and Mueller (1992) has been used to measure overall job satisfaction. Likert scale range from extremely disagree (1) to strongly agree (5). Sample item of this scale is "I like my job better than the average person."

\subsubsection{POP}

15 items perception of organizational politics scale by Kacmar and Carlson (1997) has been used to collect data about POP. This scale consists of three subscales named general political behaviour two items (example "People in this organization attempt to build themselves up by tearing others down"), go along to get ahead 7 items (example "Agreeing with powerful others is the best alternative in this organization") and pay and promotion policy six items (example "Promotions around here are not valued much because how they are determined is so political").

An additive measure by using the average of all items has been used to find an overall score of POP. It has done in two steps, first average of subscales have been taken and then average of averages taken to get overall scores. There are evidences of such overall score calculation existed in the literature such as Randall, et al. (1999); Rosen, Levy, and Hall (2006).

\subsubsection{Supportive organizational climate}

Rogg et al. (2001) questionnaire, which has considerable psychometric support, has been used to measure supportive organizational climate. A slightly modified questionnaire consists of 12 questions from three dimensions named management support, peer support and department support. Modification has been done to match to context of the study. Sample items consist of management support: "Management follow through on commitments", peer support: "Faculty trust each other", department support: "Departments cooperate to get the job done effectively and efficiently" and responses as other questionnaires 5 point likert scale ranging from 1=strongly disagree to $5=$ =strongly agree.

\section{Statistical Analysis}

Statistical analysis program named SPSS has been used to analyze the data of this study. To determine minimum and maximum scores, mean, standard deviation, kurtosis and skewness of all the variables descriptive statistics have been conducted at the beginning. Guidelines for asymmetry and skewness have been adopted from George and Mallery (2010) which states that acceptable range is -2 to +2 for univariate normal distribution. To check the hypotheses (relationships) Pearson's correlation analysis has been conducted. To determine efficacy level as well as mediating role regression analysis has been conducted.

\section{Results}

\subsection{Descriptive Analysis}

Descriptive analyses of all studied variables are shown in Table 1. George and Mallery (2010) standard to demonstrate normality has been used. It is clear from the table that data set of this research are normally distributed without any exception. Reliability of the questionnaire is also tested; all three variable questionnaires found moderate to highly reliable. 
Table 1: Descriptive Statistics

\begin{tabular}{|l|c|c|c|c|c|c|c|}
\hline \multirow{2}{*}{ Mean } & $\mathrm{N}$ & & Std. Deviation & \multicolumn{2}{c|}{ Skewness } & \multicolumn{2}{c|}{ Kurtosis } \\
\cline { 2 - 8 } & Statistic & Statistic & Statistic & Statistic & Std. Error & Statistic & Std. Error \\
\hline Gender & 105 & 1.4000 & .49225 & .414 & .236 & -1.864 & .467 \\
Age & 105 & 2.7524 & .94849 & -.171 & .236 & -.944 & .467 \\
Years of Teaching & 105 & 2.2952 & .80770 & -.591 & .236 & -1.215 & .467 \\
Income per month in Thai baht & 105 & 1.6857 & .46646 & -.812 & .236 & -1.368 & .467 \\
OC & 105 & 3.0724 & .67420 & .248 & .236 & -1.228 & .467 \\
POP & 105 & 3.4133 & .50926 & -.254 & .236 & -1.193 & .467 \\
Job Satisfaction & 105 & 3.1200 & .58743 & -.565 & .236 & -1.031 & .467 \\
Valid N (listwise) & 105 & & & & & & \\
\hline
\end{tabular}

\subsection{Correlation Analysis}

To determine relationship between perceived organizational politics, organizational climate and job satisfaction Pearson's correlation analysis has been run. Findings show that job satisfaction has a significant positive relationship with supportive organizational climate $(r=850, p \leq 0.01)$ and significant negative relationship with perceived organizational politics $(r=-.813, p \leq 0.01)$. But the subscales of POP does not show consistent result, two dimensions of POP, General political Behavior and Pay and Promotion Policy show significant negative relationship with job satisfaction, $(\mathrm{r}=-.642$, $p \leq 0.01)$ and $(r=-.891, p \leq 0.01)$, but one dimension named Go Along to Get Ahead shows insignificant relationship. On the contrary, all the subscales of organizational climate show significant positive relationship with job satisfaction.

Table 2: Correlations

\begin{tabular}{|ll|c|c|c|}
\hline & & Job Satisfaction & POP & OC \\
\hline \multirow{4}{*}{ Job Satisfaction } & Pearson Correlation & 1 & $-.813^{* *}$ & $.850^{* *}$ \\
& Sig. (2-tailed) & & .000 & .000 \\
& $N$ & 105 & 105 & 105 \\
POP & Pearson Correlation & $-.813^{* *}$ & 1 & $-.583^{* *}$ \\
& Sig. (2-tailed) & .000 & & .000 \\
& $N$ & 105 & 105 & 105 \\
OC & Pearson Correlation & $.850^{* *}$ & $-.583^{* *}$ & 1 \\
& Sig. (2-tailed) & .000 & .000 & \\
& $\mathrm{~N}$ & 105 & 105 & 105 \\
\hline \multirow{2}{*}{ **. Correlation is significant at the 0.01 level (2-tailed). } & & &
\end{tabular}

Table 2A: Correlations

\begin{tabular}{|l|c|c|c|c|c|c|c|c|}
\hline \multicolumn{2}{|c|}{} & Job Satisfaction & POP_GP & POP_GAGPOP_PP & OC_MS & OC_PS & OC_DS \\
\hline \multirow{3}{*}{ Job Satisfaction } & Pearson Correlation & 1 & $-.642^{* *}$ & -.070 & $-.891^{* *}$ & $.623^{* *}$ & $.851^{* *}$ & $.795^{* *}$ \\
\cline { 2 - 9 } & Sig. (2-tailed) & & .000 & .479 & .000 & .000 & .000 & .000 \\
\cline { 2 - 9 } & $\mathrm{N}$ & 105 & 105 & 105 & 105 & 105 & 105 & 105 \\
\hline
\end{tabular}

\subsection{Regression Analysis}

To check whether organizational climate has a mediating role between the relationship of POP and job satisfaction a multiple regression analysis has been conducted. This study follows Baron and Kenny (1986) three steps process to test mediation. At the first step mediator shoud be predicted by the independent variable, next step is to check whether mediator is a predictor of dependent variable. The final step is to checking predictor role of independent variable of dependent variable controlling the mediator. All the steps are conducted, but no mediation of supportive organizational climate is found on POP-job satisfaction relationship at the final step. To get more details result this study also checks the mediating role of POP on supportive organizational-job satisfaction relationship. Table $3 \mathrm{~A}$ and $3 \mathrm{~B}$ shows the detail process of this mediation check. 
Table 3A: Coefficientsa

\begin{tabular}{|l|c|c|c|c|c|}
\hline \multirow{2}{*}{ Model } & \multicolumn{2}{|c|}{ Unstandardized Coefficients } & Standardized Coefficients & \multirow{2}{*}{ T } & \multirow{2}{*}{ Sig. } \\
\cline { 2 - 5 } & $\mathrm{B}$ & Std. Error & Beta & & \\
\hline 1 (Constant) & 6.322 & .228 & & 27.707 & .000 \\
Perceived Organizational Politics & -.938 & .066 & -.813 & -14.188 & .000 \\
(Constant) & 3.493 & .255 & & 13.671 & .000 \\
2Perceived Organizational Politics & -.555 & .050 & -.482 & -11.180 & .000 \\
Organizational Climate & .496 & .038 & .569 & 13.210 & .000 \\
\hline
\end{tabular}

a. Dependent Variable: Job Satisfaction

Table 3B: Coefficientsa

\begin{tabular}{|c|c|c|c|c|c|}
\hline \multirow{2}{*}{ Model } & \multicolumn{3}{|c|}{ Unstandardized Coefficients Standardized Coefficients } & \multirow{2}{*}{$\mathrm{T}$} & \multirow{2}{*}{ Sig. } \\
\hline & B & Std. Error & Beta & & \\
\hline (Constant) & .845 & .142 & & 5.939 & 0 \\
\hline $\begin{array}{l}\text { Organizational Climate } \\
\text { (Constant) }\end{array}$ & $\begin{array}{l}.740 \\
3.493\end{array}$ & $\begin{array}{l}.045 \\
.255\end{array}$ & .850 & \begin{tabular}{|l|}
16.360 \\
13.671
\end{tabular} & 000 \\
\hline 2Organizational Climate & .496 & .038 & .569 & 13.210 & 000 \\
\hline Perceived Organizational Politics & .555 & .050 & -.482 & -11.180 & .0 \\
\hline
\end{tabular}

a. Dependent Variable: Job Satisfaction

\section{Discussion}

This study is aimed to explore the relationship between perceived organizational politics, organizational climate and job satisfaction in Thai higher education sector. Furthermore, this study checks relationship of the dimensions of POP with job satisfaction.

Result of this study shows strong negative relationship between job satisfaction and perceived organizational politics which is supported by several previous research (Kacmar \& Baron, 1999; Ferris et al., 1989; Cropanzano et al., 1997). This result implies that the relationship between POP and job satisfaction is also valid for higher education sector of Thailand.

Only exception found here is the insignificant relationship of one sub dimension of POP, go along to get ahead, with job satisfaction. It brings an option to rethink about the components of POP or the dimensions to include in POP in this sector.

Similarly, result shows a strong positive relationship of job satisfaction with supportive organizational climate. One such research has been conducted by Luthans et al. (2008), though their research relates supportive organizational climate with performance; this study shows similar result with job satisfaction.

Moreover, from the regression analysis both POP and supportive organizational climate proved to be strong predictor of job satisfaction. Which implies higher perceived organizational politics brings lower job satisfaction and higher supportive organizational climate bring higher job satisfaction in the Thai higher education sector.

This study further examines the mediating role of supportive organizational climate on POP-job satisfaction relationship. But result of that analysis does not satisfy the criteria; hence, supportive organization climate does not mediate the above mentioned relationship.

Result of this study emphasizes that to get better performance in Thai higher education institutes organization politics should be minimized. Education institutes also need to figure out causes behind such behaviour in their organizations. Study result also suggests that supportive organizational climate could be one helpful tool to eliminate political behaviour in the organizations. Moreover this study also shows a strong relationship between supportive organization climate and job satisfaction which means implementing a supportive climate might bring healthy organization culture which nurture high performance and job satisfaction.

\section{Limitation and Conclusion}

In conclusion, it could be claimed that this study extended the literature by empirically demonstrating the relationship 
between organizational politics perception, supportive organizational climate and job satisfaction. But it is not beyond limitation. This research suffers from several limitations which important to mention here for proper understanding of the result findings and for direction of further research. Firstly only private higher education institutes are considered while collecting data which could be a major drawback to generalize the result in higher education sector. Public institutes have different working environment and management system which may influence the result of this study. Moreover, this study conducted in a specific region of Thailand with a limited number of institutions. Although the number of respondents is adequate to test the variables, it is difficult to comment on the general nature of the sector from few institutions. Furthermore, organizational culture in oriental countries, especially one like Thailand, may have huge impact on the responses of the respondents. Although confidentiality is always maintained with strict ethical standard, people are reluctant to disclose their feelings as negative responses are not viewed positively here. Finally some other variables might have impact on the relationships which are not considered here such as leadership behaviour, job facilities, workload and so on.

Findings from this study suggests that while faculty perceived higher organizational politics, their job satisfaction is at lower level and vice versa; on the contrary the more the organization climate supportive faculty are more satisfied and vice versa. To produce better graduates and better citizen job satisfaction of faculty is important and that is why such researches should be taken seriously.

\section{Recommendation for Future Research}

There are opportunities for future research in this field. Future research should consider wider geographical area and larger sample size which could give a more generalized picture of the study. Either both public and private organizations should be included in the study or comparative studies could be conducted to determine differences. Incorporating above mentioned variables in the study might be a plus for the result. It is worthy to mention here that this study does not suggest generalization beyond population rather provides an idea of how studied variables interact and areas needed development of the sector.

\section{References}

Agho, A. O., Price, J. L. \& Mueller, C. W. (1992). Discriminant validity of measures of job satisfaction, positive affectivity, and negative affectivity. Journal of Occupational Psychology, 65, 185-196.

Baron, R. M., \& Kenny, D. A. (1986). The moderator-mediator variable distinction in social psychological research: Conceptual, strategic, and statistical considerations. Journal of Personality \& Social Psychology, 51, 1173-1182.

Bozeman, D. P., Perrewe, P. L., Hochwarter, W. L., Kacmer, K. M., \& Brymer, R. A. (1996). An examination of reactions to perception of politics. Paper presented at Annual Southern Management Association Meeting, New Orleans, LA

Breaux, D.M., Munyon, T. P., Hochwarter, W. A., \& Ferris, G. R. (2009). Politics as a Moderator of the Accountability-Job Satisfaction Relationship: Evidence across three studies. Journal of Management, 35, 307326.

Cropanzano, R. S., Howes, J. C., Grandey, A. A. \& Toth. P. (1997). The relationship of organizational politics and support to work behaviors, attitudes, and stress. Journal of Organizational Behavior, 18, 159-180.

Cropanzano, R.S., Kacmar, K. M. \& Bozeman, D. P. (1995). Organizational politics, justice and support: Their differences and similarities. In R.S. Cropanzano and K.M. Kacmar (eds.) Organizational Politics. Justice and Support: Managing Social Climate of the Workplace, I-IX. Westport, CT: Quorum Books.

Drory, A., \& Romm, T. (1990). The definition of organizational politics: A review. Human Relations, 43 (11), 1133-1154.

Eisenberger, R., Fasolo, P., \& Davis-LaMastro, V. (1990). Perceived organizational support and employee diligence, commitment, and innovation. Journal of Applied Psychology, 75, 51-59.

Fandt, P.M., \& Ferris, G. R. (1990). The management of information and impressions: when employees behave opportunistically." Organizational Behavior and Human Decision Processes, 45, 140-158.

Ferris, G. R., \& Kacmar, K. M. (1992). Perceptions of organizational politics. Journal of Management, 18, 93-1 16.

Ferris, G.R., \& King, T. R. (1991). Politics in human resource decisions: A walk on the dark side. Organizational Dynamics, 20, 59 -71.

Ferris, G.R., Adams, G., Kolodinsky, R. W., Hochwarter, W. \& Ammeter, A. P. (2002). Perceptions of organizational politics: theory and research directions. In The Many Faces of Multi-level Issues, F.J. Yammarino and F. Dansereau (eds.), 179-254. Bingley: Emerald.

Ferris, G.R., Fedor, D., Chachere, J.G. \& Pondy, L. (1989). Myths and politics in organizational contexts. Group \& Organizational Studies, 14, 83-103.

Ferris, G.R., Frink, D. D., Galang, M. C., Zhou, J., Kacmar, K. M., \& Howard, J. L. (1996). Political work environments. Human Relations, 49, 233-266.

Ferris, G.R., Russ, G. S., \& Fandt, P. M. (1989). Politics in Organizations. In Impression Management in the Organization, R.A. Giacalone and P. Rosenfeld (eds), 143-170. Hillsdale, NJ: Lawrence Erlbaum. 
Frost, P. J. (1987). Power, politics, and influence." In F. Jablin, L. Putnam, K. Roberts, and L. Porter. (eds.), Handbook of Organizational Communication, Beverly Hills, CA: Sage.

Gandz, J., \& Murray, V. V. (1980). The experience of workplace politics. Academy of Management Journal, 23, 231-251.

George D \& M Mallery (2010) SPSS for Windows Step by Step: A Simple Guide and Reference, 17.0 update (10a ed.) Pearson: Boston

Gohel, K. (2012). Psychological capital as a determinant of employee satisfaction. International Referred Research Journal, 3 (36), 3437.

Islam, R., Rasul, T. \& Ullah, W. (2012). Analysis of the factors that affect job satisfaction: a case study on private companies employees of Bangladesh. European Journal of Business and Management, 4 (4), 35-46.

Judge, T. A. \& Bretz, R. D. (1994). Political influence behaviour and career success. Journal of Management, 20, 43-65

Kacmar, K. M., \& Baron, R. R. (1999). Organizational politics: The state of the field, links to related processes, and an agenda for future research. Research in Personnel and Human Resources Management, 17, 1-39.

Kacmar, K.M., \& Carlson, D. S. (1997). A further validation of the perceptions of politics scale (POPS): A multiple-sample investigation. Journal of Management, 23, 627-658.

Kacmar, K.M., \& Ferris, G. R. (1991). Perceptions of organizational politics scale (POPS): Development and construct validation. Educational and Psychological Measurement, 51, 193205.

Keeley, M. (1988). A social-contract theory of organizations. Notre Dame, IN: University of Notre Dame Press.

Khalid, J. \& Ahmed, J. (2016). Perceived organizational politics and employee silence: supervisor trust as a moderator. Journal of the Asia Pacific Economy, 21(2), 174-195, DOI: 10.1080/13547860.2015.1092279

Ko, W. H. (2012). The relationships among professional competence, job satisfaction and career development confidence for chefs in Taiwan. International Journal of Hospitality Management, 31, 1004-1011.

Luthans, F., Norman, S. M., Avolio, B. J. \& Avey, J. B. (2008). The mediating role of psychological capital in the supportive organizational climate-employee performance relationship. Journal of Organizational Behavior, 29, 219-238.

Mercer, A., \& Bilson, K. (1985). Factors influencing organizational commitment by physicians. Academy of Management Proceedings, 72-76.

Mintzberg, H. (1983). Power in and around organizations. Englewood Cliffs, NJ: Prentice-Hall.

Mintzberg, H. (1985). Organization as political arena. Journal of Management Studies, 22, 133-54

Porter, L.W. (1976). "Organizations as Political Animals." Presidential address, Division of Industrial Organizational Psychology, 84th Annual Meeting of the American Psychological Association, Washington, DC

Porter, L.W., Allen, R. W., \& Angle, H. L. (1981). The politics of upward influence in organizations. In L.L. Cummings and B.M. Staw (eds.) Research in Organizational Behavior, Vol. 3, 109-149. Greenwich, CT: JAI Press.

Randall, M. L., Cropanzano, R., Bormann, C. A., \& Birjulin, A. (1999). Organizational politics and organizational support as predictors of work attitudes, job performance, and organizational citizenship behaviour. Journal of Organizational Behaviour, 20, 159-169

Rhoades, L., Eisenberger, R., \& Armeli, S. (2001). Affective commitment to the organization: The contribution of perceived organizational support. Journal of Applied Psychology, 86, 825-836.

Rogg, K. L., Schmidt, D. B., Shull, C., \& Schmitt, N. (2001). Human resource practices, organizational climate, and customer satisfaction. Journal of Management, 27, 431-449.

Rosen, C. C., Levy, P. E., \& Hall, R. J. (2006). Placing perceptions of politics in the context of the feedback environment, employee attitudes, and job performance. Journal of Applied Psychology, 91(1), 211-220. http://dx.doi.org/10.1037/0021-9010.91.1.211

Schermerhorn, J. R., Jr., Gardner,W. L., \& Martin, T. N. (1990). Management dialogues: Turning on the marginal performer. Organizational Dynamics, 18, 47-59.

Selamat, N., Samsu, N. Z. \& Kamalu, N. S. M. (2013). The impact of organizational climate on teachers job performance. Educational Research 2(1), 71-82

Thompson, M. D. (2005). Organizational climate perception and job element satisfaction: A multi-frame application in a higher education setting. E-Journal of Organizational Learning and Leadership, 4(1)

Vigoda-Gadot, E., \& Talmud, I. (2010). Organizational politics and job outcomes: The moderating effect of trust and social support. Journal of Applied Social Psychology, 40(11), 28292861.

Yang, Jen-Te, (2010). Antecedents and consequences of job satisfaction in the hotel industry, International Journal of Hospitality Management, 29(4), 609-619, http://dx.doi.org/10.1016/j.jhm.2009.11.002. 